\title{
Morphometric Analyses of the Caroticoclinoid and Interclinoid Foramina: A Study in Brazilian Dry Skulls
}

\author{
Análisis Morfométricos del Foramen Caroticoclinoideo e Interclinoideo: \\ Un Estudio en Cráneos Secos Brasileños
}

\begin{abstract}
Kennedy Martinez de Oliveira ${ }^{1}$; Valério Landim de Almeida ${ }^{1}$; Gabriel das Chagas Benevenuto ${ }^{2}$; Gustavo Maia de Faria ${ }^{2}$; Ana Clara Camillato e Silva ${ }^{2}$; Thayná Cristina Ferreira $\mathrm{Costa}^{3}$; Daniel Gonçalves de Oliveira ${ }^{2}$; Leonardo Braga Bueno ${ }^{2}$; Pedro Lucas Rodrigues ${ }^{2}$; Marcos Túlio Castro Peixoto ${ }^{2}$; Talita Cardoso Gomes²; Maísa de Fátima Satiro Oliveira ${ }^{4}$; Giuliano Roberto Gonçalves ${ }^{5} \&$ Leandro Henrique Grecco ${ }^{6}$
\end{abstract}

DE OLIVEIRA, K. M.; DE ALMEIDA, V. L.; BENEVENUTO, G. C.; DE FARIA, G. M.; SILVA, A. C. C.; COSTA, T. C. F.; DE OLIVEIRA, D. G.; BUENO, L. B.; RODRIGUES, P. L.; PEIXOTO, M. T. C.; GOMES, T. C.; OLIVEIRA, M. F. S.; GONÇALVES, G. R. \& GRECCO, L. H. Morphometric analyses of the caroticoclinoid and interclinoid foramina: A study in Brazilian dry skulls. Int. J. Morphol., 39(5):1345-1352, 2021.

SUMMARY: The caroticoclinoid (CF) and the interclinoid (IF) foramina are variant formations of the middle cranial fossa, which result from idiopathic and possibly atavistic ossifications of the caroticoclinoid and interclinoid ligaments, respectively. Topographically, these foramina are intimately associated, to varying degrees, depending on their conformations, with the neurovascular elements of the paraclinoid region and have important clinical and surgical significance. Thus, this study, conducted from 38 dry skulls belonging to the shared collection of the Federal University of Juiz de Fora, Governador Valadares campus, revealed 11 skulls (28.95\%) with one of the two complete formations - the caroticoclinoid or the interclinoid, and in 6 skulls the caroticoclinoid foramen occurred uni or bilaterally. As a result, $50 \%$ of these skulls presented the CF exclusively on the right (or $62.5 \%$ of the total number of variant foramina), with an average transverse diameter of $4.91 \mathrm{~mm}$ and $5.8 \mathrm{~mm} \mathrm{AP}$ (anteroposterior) diameter and an average area of $22.5 \mathrm{~mm}^{2}$. Concerning the IF, the findings occurred in 5 skulls with variable distributions between the clinoid processes and lateralities. The average length of the bone bridges in the IF was $7.7 \mathrm{~mm}$. In conclusion, detailed anatomical knowledge of the caroticoclinoid and the interclinoid foramina is fundamental to the practice of neurosurgical procedures, since they have intimate relationships at a location of high structural complexity.

KEY WORDS: Caroticoclinoid and surgery; Caroticoclinoid foramen and caroticoclinoid ligament.

\section{INTRODUCTION}

The ossifications of the skull base is a complex process that begins in the fourth week of gestation from the neural crest cells and mesoderm. As the ossification of the lesser wing of the sphenoid bone, it occurs between the 17th and 18th week of intrauterine life and continues after birth until two years of age (Beger et al., 2020). The lesser wing of the sphenoid bone is a reference for neurosurgical procedures and presents, at its extremity, the anterior clinoid process (ACP) (Isolan et al., 2020; Prathiba et al., 2020; Singh et al., 2021). The ACP is a posteromedial bony projection of the lesser wing of the sphenoid bone and the lateral wall of the optic canal, having three fixations: one medial, to the sphenoid plane, one laterally, on the lesser wing of the sphenoid bone and one inferomedial, forming the optic strut (Chaddad-Neto et al., 2020). Additionally, it is possible to divide the ACP into four distinct areas - the medial, lateral, superior, and posterior triangle (Xu et al., 2020).

The medial clinoid process (MCP) is a small and variable bony structure in humans, with distinct dimensions and located anterolaterally to the sella turcica and at the transition from the cavernous part of the ICA (medial to the

\footnotetext{
${ }^{1}$ Department of Basic Life Sciences, Federal University of Juiz de Fora, Minas Gerais, Brazil.

${ }^{2}$ Faculty of Medicine, Federal University of Juiz de Fora, Minas Gerais, Brazil.

${ }^{3}$ Faculty of Odontology, Federal University of Juiz de Fora, Minas Gerais, Brazil.

${ }^{4}$ Faculty of Medicine, Federal University of Minas Gerais, Minas Gerais, Brazil.

${ }^{5}$ School of Medicine, São Leopoldo Mandic, São Paulo, Brazil.

${ }^{6}$ São Leopoldo Mandic Institute and Research Center, Brazil.
} 
DE OLIVEIRA, K. M.; DE ALMEIDA, V. L.; BENEVENUTO, G. C.; DE FARIA, G. M.; SILVA, A. C. C.; COSTA, T. C. F.; DE OLIVEIRA, D. G.; BUENO, L. B.; RODRIGUES, P. L.; PEIXOTO, M. T. C.; GOMES, T. C.; OLIVEIRA, M. F. S.; GONÇALVES, G. R. \& GRECCO, L. H. Morphometric analyses of the caroticoclinoid and interclinoid foramina: A study in Brazilian dry skulls. Int. J. Morphol., 39(5):1345-1352, 2021.

anterior syphon knee) to the paraclinoid part of the ICA (Sharma et al., 2019).

The posterior clinoid process (PCP) is situated posteriorly to the roof of the cavernous sinus, on the superior and lateral faces of the dorsum of the sella turcica (Isolan et al.). These clinoid processes are connected by ligaments under folds of the cranial dura mater and are subject to ossification with formation of foramina - caroticoclinoid and interclinoid (Fig. 1).

In the sphenoid bone, in addition to the intracranial ligaments, the petrosphenoid, the caroticoclinoid (CL) and the interclinoid, there are variant and atavistic extracranial ligamentous formations that are also subject to ossificationthe pterygospinous ligament and the pterygoalar ligament (de Oliveira et al., 2021).

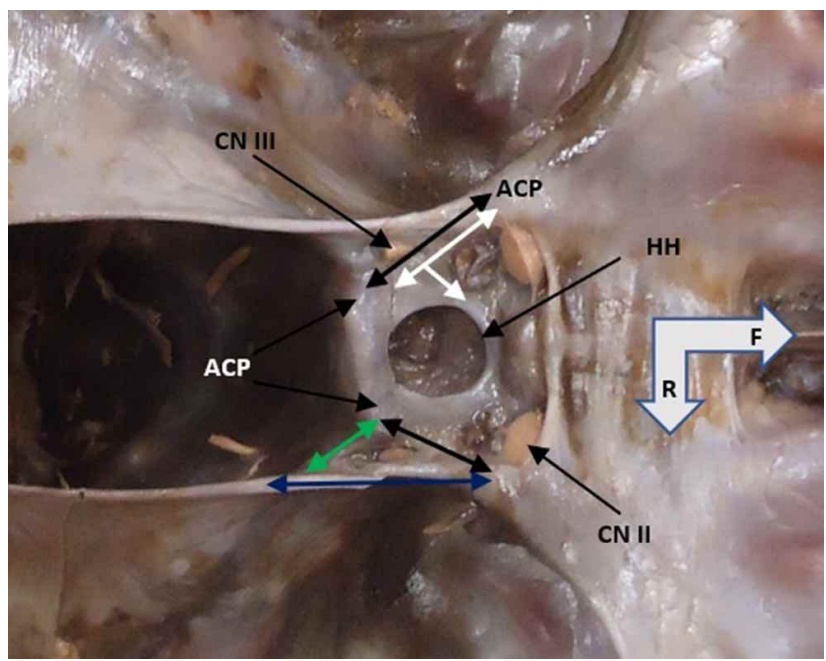

Fig. 1. The interface between the anterior and middle cranial fossa and their dura mater topographies. The bilateral double black arrows indicate the interclinoid folds, related in depth to the interclinoid ligaments, the green arrow is overlapping the posterior petroclinoid fold and the underlying petrosphenoidal ligament, the blue arrow is overlapping the anterior petroclinoid fold and its ligament, the white arrow is overlapping, through the dura mater, to the caroticoclinoid ligament. ICA (internal carotid artery), HH (hypophyseal hiatus), ACP (anterior clinoid process), PCP (posterior clinoid process), CN II (II cranial nerve pair), CN III (III cranial nerve pair). The triangular configuration between the anterior and posterior petroclinoid folds and the interclinoid fold is the oculomotor nerve trigone. F (frontal) and R (right).

The objective of this study is to indicate the incidence of the caroticoclinoid foramen (CF) - or caroticoclinoid canal (CC) - and the interclinoid foramen (IF) in the collection of dried human skulls from the Federal University of Juiz de Fora - Governador Valadares campus, as well as their morphometric characteristics and the principal clinical and surgical repercussions attributed to these variations.

\section{MATERIAL AND METHOD}

We analyzed 38 skulls from the shared collection of the Human Anatomy laboratory of the Federal University of Juiz de Fora, Governador Valadares campus (UFJF-GV) throughout 2019. Analyses were conducted under ambient light, with unarmed vision and with the use of morphometric techniques by using a digital pachymeter (Western Pro), resolution $0.1 \mathrm{~mm}$, Rhosse ${ }^{\circledR}$ stainless steel millimeter ruler and $\mathrm{JON}{ }^{\circledR}$ stainless steel dry point compass. All were evaluated by direct cranioscopy and by a unique examiner from the $\mathrm{CF}$ and IF perspective, considering the microregional integrity of the paraclinoid region and the typical structural conformation of a natural and complete (closed) foramen - incomplete forms were not considered in this study. None of the specimens were identified as to sex and/or age.

The literature search was performed in the Medical Literature Analysis and Retrieval System Online (Medline / Pubmed) databases. We used the descriptors "caroticoclinoid", "caroticoclinoid and surgery", "anterior clinoid process and anatomic variation", "sphenoid bone and surgery", "caroticoclinoid canal", "caroticoclinoid foramen" and "caroticoclinoid ligament". The descriptors "surgery", "sphenoid bone" and "anatomic variation" were indexed in Medical Subject Heading Terms (MeSH), while the others were inserted due to relevance to the study. Studies in the temporal space from 2017 to 2021, available in digital media and in the English language, beyond that a historical reference were included.

\section{RESULTS}

From the analysis of 38 skulls in the collection, all mesocephalic, it was observed that $11(28.95 \%)$ presented at least one of the two formations - the CF (or CC) and the IF, complete, simultaneous in some finds ( 3 occurrences in a total of 16 formations) and with variable conformations as to diameters, lengths and areas. Thus, the CF, typically formed by a osseous bridge between the anterior and middle clinoid processes (Fig. 2), was found in 6 skulls (8 foramina) with the following distributions: in 2 skulls the canal occurred bilaterally, in one skull the occurrence was on the left, and in the next three skulls the occurrences were on the right laterality. Therefore, the incidence of $\mathrm{CF}$ on the right side was $62.5 \%$, considering the total of the 8 unilateral and bilateral formations. In relation to right unilateral variation, the occurrence was 50 $\%$ in the 6 skulls (Table I). Here we did not consider the CF formations associated with IF (3 findings). 
DE OLIVEIRA, K. M.; DE ALMEIDA, V. L.; BENEVENUTO, G. C.; DE FARIA, G. M.; SILVA, A. C. C.; COSTA, T. C. F.; DE OLIVEIRA, D. G.; BUENO, L. B.; RODRIGUES, P. L.; PEIXOTO, M. T. C.; GOMES, T. C.; OLIVEIRA, M. F. S.; GONÇALVES, G. R. \& GRECCO, L. H. Morphometric analyses of the caroticoclinoid and interclinoid foramina: A study in Brazilian dry skulls. Int. J. Morphol., 39(5):1345-1352, 2021.

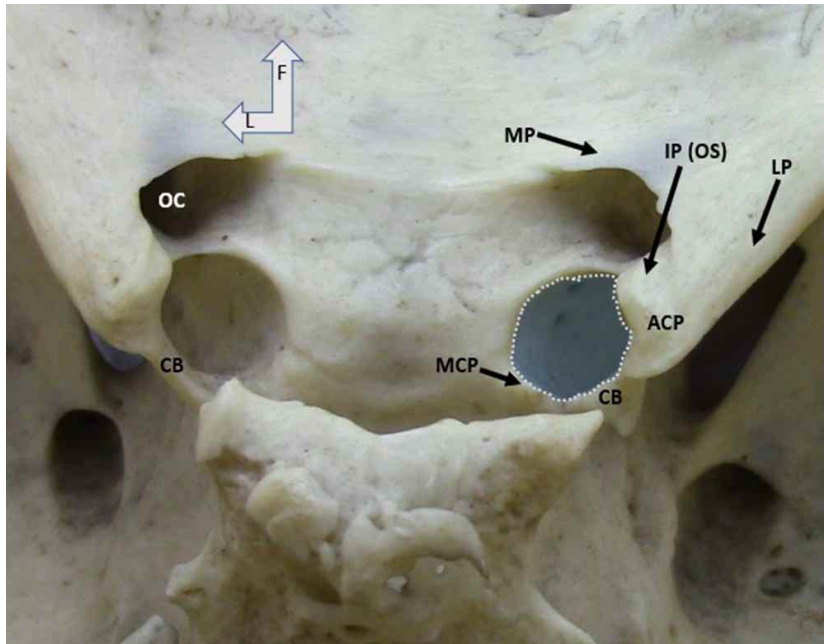

Fig. 2. Right unilateral occurrence of the complete caroticoclinoid bone bar $(\mathrm{CB})$ with the blue oval circle. MCP (middle clinoid process), ACP (anterior clinoid process) and their fixations: IP/OS (inferior pillar / optic strut), LP (lateral pillar), MP (medial pillar). OC (optic canal). F ( frontal) and L ( left).

Table I. Absolute (FI) and relative (RF) frequencies according to the presence or absence of the $\mathrm{CF}$ in skulls from the collection of the authors. ACP - anterior clinoid process, MCP - middle clinoid process.

\begin{tabular}{lcc}
\hline $\begin{array}{l}\text { Caroticoclinoid } \\
\text { foramen (CF) }\end{array}$ & $\begin{array}{c}\text { Absolute } \\
\text { Frequency (FI) }\end{array}$ & $\begin{array}{c}\text { Relative } \\
\text { Frequency (RF) }\end{array}$ \\
\hline Bilateral & 2 ACP/MCP & $33.33 \%$ \\
Unilateral left & 1 ACP/MCP & $16.66 \%$ \\
Unilateral right & 3 ACP/MCP & $50 \%$ \\
Total & 6 skulls (8 & $100.00 \%$ \\
& foramina) & \\
\hline
\end{tabular}

The $\mathrm{T}$ diameter (transverse) of each of the foramen was measured from the internal margin of the anterior clinoid process to the base of the middle clinoid process (Fig. 3), with an average of $4.91 \mathrm{~mm}$; the foramina on the right had an average of $4.84 \mathrm{~mm}$, and the foramina on the left had an average of $5.03 \mathrm{~mm}$ (Table III).

As for the AP (anteroposterior) diameter, the measurement was made from the central portion of the inferior margin of the optic canal to the internal margin of the bone bar between the anterior and middle clinoid processes (Fig. 3), with an average of $5.82 \mathrm{~mm}$, and the right foramina had an average of $5.68 \mathrm{~mm}$, and the left foramina had an average of $6.07 \mathrm{~mm}$ (Table III).

The resulting area of the CFs was, by Radinsky's formula ( $\pi \mathrm{x} \mathrm{w} \mathrm{x} \mathrm{h} \mathrm{/} \mathrm{4),} \mathrm{on} \mathrm{average,} 22.5 \mathrm{~mm}^{2}$ with the right-located foramina averaging $21.6 \mathrm{~mm}^{2}$ and the leftlocated foramina $24.1 \mathrm{~mm}^{2}$. As for the IF (Fig. 4), the findings occurred in 5 skulls with the following distributions: 3 skulls with bilateral formations (in two the bone bridges occurred bilaterally between the three clinoid processes, and, in the third skull, the bridge extended between the anterior and posterior clinoid processes) - thus, an association between the IF and the CF (not treated morphometrically). In one of the skulls, the IF occurred on the left, between the three clinoid processes, and in the fifth skull, the osseous bridge connected the ACP to the PCP (Table II).

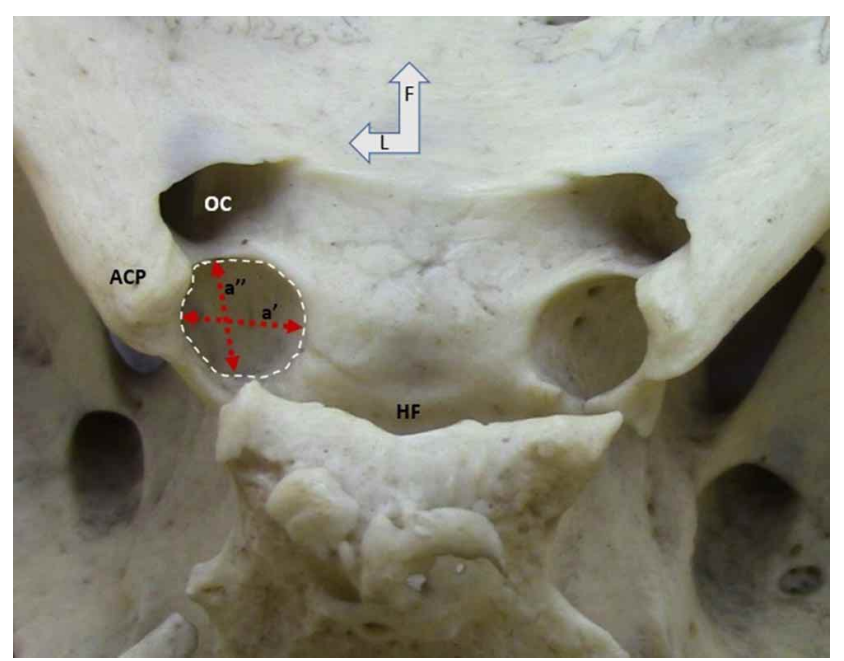

Fig. 3. Complete right caroticoclinoid foramen with the representations of the measures a' (transverse diameter) and a" (AP - anteroposterior diameter). ACP (anterior clinoid process), HF (hypophyseal fossa), OC (optic canal). F (frontal) and L (left).

Table II. Absolute (FI) and relative (RF) frequencies according to the presence or absence of IF in skulls from the collection of the authors. ACP - anterior clinoid process, MCP - middle clinoid process, and PCP - posterior clinoid process.

\begin{tabular}{llc}
\hline Interclinoid & Absolute Frequency (FI) & Relative \\
\hline Bilateral & 2 ACP/MCP/PCP + 1 & $60 \%$ \\
Unilateral left & 1 ACP/MCP/PCP & $20 \%$ \\
Unilateral right & 1 ACP/PCP & $20 \%$ \\
Total & 5 skulls (8 foramina/bone bars) & $100.00 \%$ \\
\hline
\end{tabular}

The incidence of IF for the right and left antimere, considering the formations in the 5 skulls ( 8 foramina), was $50 \%$, and in $60 \%$ of these skulls the incidence was bilate$\mathrm{ral}$. The average length of the osseous bridge from the ACP to the PCP was $7.7 \mathrm{~mm}$, as indicated in Figure 3 and Table IV. The standard deviation (SD) of the AP diameter, T diameter, and $\mathrm{CF}$ area were $0.53 \mathrm{~mm}, 0.42 \mathrm{~mm}$, and 3.43 $\mathrm{mm} 2$. respectively, while the SD of the ACP / PCP bone bar length was $0.51 \mathrm{~mm}$ (Table III). 
DE OLIVEIRA, K. M.; DE ALMEIDA, V. L.; BENEVENUTO, G. C.; DE FARIA, G. M.; SILVA, A. C. C.; COSTA, T. C. F.; DE OLIVEIRA, D. G.; BUENO, L. B.; RODRIGUES, P. L.; PEIXOTO, M. T. C.; GOMES, T. C.; OLIVEIRA, M. F. S.; GONÇALVES, G. R. \& GRECCO, L. H. Morphometric analyses of the caroticoclinoid and interclinoid foramina: A study in Brazilian dry skulls. Int. J. Morphol., 39(5):1345-1352, 2021.

Table III. Morphometrics of the variant skulls for CF (caroticoclinoid foramen); 01 (skull 01), 02 (skull 02 ), 03 (skull 03 ), 04 (skull 04 ), 05 (skull 05) and 06 (skull 06). SD (standard deviation). Area: Radinsky formula ( $\pi \mathrm{x}$ w x h / 4).

\begin{tabular}{|c|c|c|c|c|c|}
\hline $\begin{array}{l}\text { Caroticoclinoid } \\
\text { foramen }(\mathrm{CF})\end{array}$ & & Location & Diameter AP & Diameter $\mathrm{T}$ & Area \\
\hline CF01 & & right & $5.7 \mathrm{~mm}$ & $5.4 \mathrm{~mm}$ & $24.2 \mathrm{~mm}^{2}$ \\
\hline CF01 & & left & $5.1 \mathrm{~mm}$ & $4.6 \mathrm{~mm}$ & $18.4 \mathrm{~mm}^{2}$ \\
\hline CF02 & & right & $5.6 \mathrm{~mm}$ & $5.1 \mathrm{~mm}$ & $22.4 \mathrm{~mm}^{2}$ \\
\hline $\mathrm{CF} 02$ & & left & $6.4 \mathrm{~mm}$ & $5.4 \mathrm{~mm}$ & $27.1 \mathrm{~mm}^{2}$ \\
\hline CF03 & & left & $6.7 \mathrm{~mm}$ & $5.1 \mathrm{~mm}$ & $26.8 \mathrm{~mm}^{2}$ \\
\hline CF04 & & right & $5.4 \mathrm{~mm}$ & $4.7 \mathrm{~mm}$ & $19.9 \mathrm{~mm}^{2}$ \\
\hline CF05 & & right & $6.1 \mathrm{~mm}$ & $4.8 \mathrm{~mm}$ & $23.0 \mathrm{~mm}^{2}$ \\
\hline CF06 & & right & $5.6 \mathrm{~mm}$ & $4.2 \mathrm{~mm}$ & $18.5 \mathrm{~mm} 2$ \\
\hline $\begin{array}{l}6 \text { skulls / } \\
\text { foramina }\end{array}$ & 8 & $\begin{array}{l}5 \text { rights and } 3 \\
\text { lefts }\end{array}$ & $\begin{array}{l}\text { Average: } 5.82 \mathrm{~mm}(\mathrm{R}= \\
5.68 \text { and } \mathrm{L}=6.07) \\
\mathrm{SD}=0.53 \mathrm{~mm}\end{array}$ & $\begin{array}{l}\text { Average: } 4.91 \mathrm{~mm}(\mathrm{R}= \\
4.84 \text { and } \mathrm{L}=5.03) \\
\mathrm{SD}=0.42 \mathrm{~mm}\end{array}$ & $\begin{array}{l}\text { Average: } 22.5 \mathrm{~mm}^{2}\left(\mathrm{R}=21.6 \mathrm{~mm}^{2}\right. \\
\left.\text { and } \mathrm{L}=24.1 \mathrm{~mm}^{2}\right) \\
\mathrm{SD}=3.43 \mathrm{~mm}^{2}\end{array}$ \\
\hline
\end{tabular}

Table IV. Morphometrics of the variant skulls for the IF (Interclinoid foramen). 01 (skull 01), 02 (skull 02), 03 (skull 03), 04 (skull 04) and 05 (skull 05). ACP - anterior clinoid process and PCP - posterior clinoid process. SD (standard deviation).

\begin{tabular}{lcc}
\hline Interclinoid Forame (IF) & Location & Bone bar Length \\
\hline FI0 1 & right & $8.0 \mathrm{~mm}$ \\
FI0 1 & left & $7.5 \mathrm{~mm}$ \\
FI02 & right & $7.5 \mathrm{~mm}$ \\
FI02 & left & $7.7 \mathrm{~mm}$ \\
FI03 & left & $8.5 \mathrm{~mm}$ \\
FI03 & right & $8.0 \mathrm{~mm}$ \\
FI04 & right & $6.75 \mathrm{~mm}$ \\
FI05 & left & $7.7 \mathrm{~mm}$ \\
5 skulls / 8 foramina & 4 rights & Average: $7.7 \mathrm{~mm}$ \\
& and 4 & SD $=0.51 \mathrm{~mm}$ \\
& lefts & \\
\hline
\end{tabular}

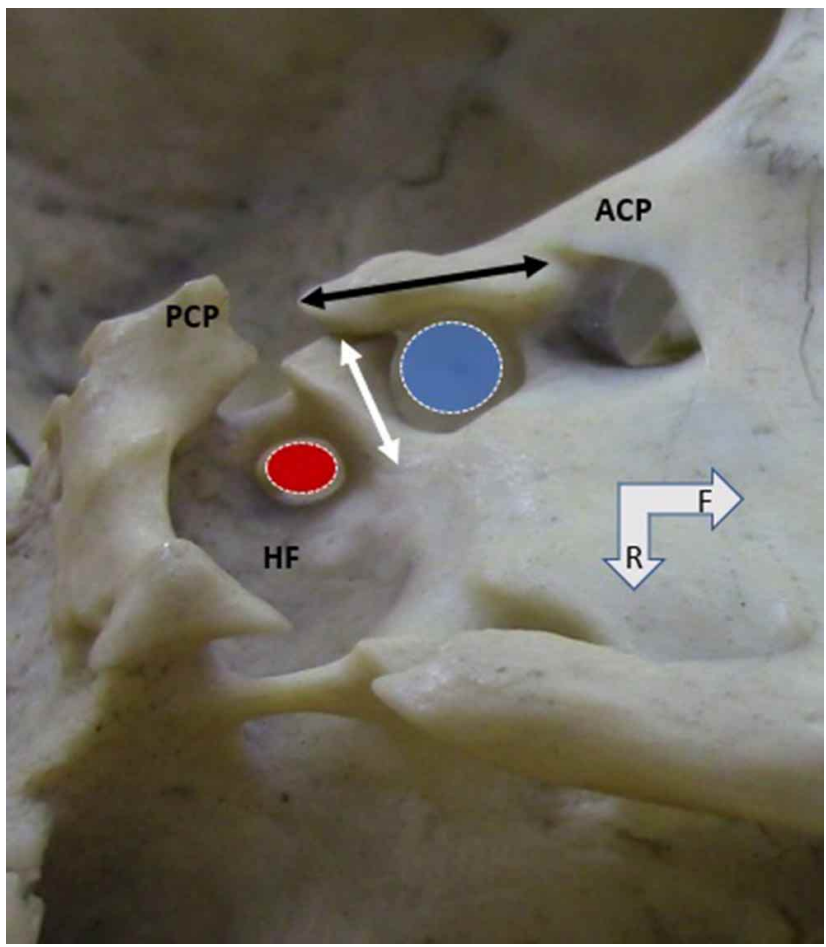

\section{DISCUSSION}

The development of the sphenoid bone occurs from the endochondral ossification of the sphenoid body during the first trimester, a process regulated by matrix Gla proteins and osteopontin. The physiological understanding of this mechanism has still not been elucidated, in view of the complexity and high variability of the genetic control of these ossification centers (Skandalakis et al., 2019).

The caroticoclinoid ligament (CL), which extends from the ACP to the MCP, when identified in human skulls, is frequently ossified, and, as a result of this anatomical variation between the clinoid processes, there is the formation of the CF (Jha et al., 2017; Zhao et al., 2020).

The CF varies in incidence and morphology and constitutes the anterior part of the cavernous sinus roof. The first mention in the literature about the $\mathrm{CF}$ was published in 1855 by Friedrich Gustav Jakob Henle, a German pathologist and anatomist, and it is generally categorized as "complete" or "incomplete" (Henle, 1855; Skandalakis et al.).

The IF occurs by ossification of the interclinoid ligament, existing between the ACP and PCP and occasionally between the MCP and PCP (JaiSankar et al., 2019; Bayrak et al., 2019; Touska et al., 2019). Although age has been pointed out as the factor responsible for the ossification of the CL, predominantly in individuals more than 50 years old, CF has also been found in embryos and

Fig. 4. Left unilateral interclinoid foramen involving the anterior (ACP), middle, and posterior clinoid processes (PCP). Double black arrow positioned on the interclinoid bone bar and double white arrow on the caroticoclinoid bone bar. Blue oval circle at the caroticoclinoid foramen and red oval circle at the interclinoid foramen. F ( frontal) and $\mathrm{R}$ (right). 
DE OLIVEIRA, K. M.; DE ALMEIDA, V. L.; BENEVENUTO, G. C.; DE FARIA, G. M.; SILVA, A. C. C.; COSTA, T. C. F.; DE OLIVEIRA, D. G.; BUENO, L. B.; RODRIGUES, P. L.; PEIXOTO, M. T. C.; GOMES, T. C.; OLIVEIRA, M. F. S.; GONÇALVES, G. R. \& GRECCO, L. H. Morphometric analyses of the caroticoclinoid and interclinoid foramina: A study in Brazilian dry skulls. Int. J. Morphol., 39(5):1345-1352, 2021.

newborns, revealing that the formation of this structure is not completely age-dependent (Skandalakis et al.).

The anterior clinoidectomy is the ideal procedure for the management of pathologies that present in the paraclinoid region, especially because of the greater exposure and visualization of the surgical area and the decreased retraction of the brain that the removal of the ACP provides. Some of the conditions that require ACP removal are: paraclinoid aneurysms in both the ICA and the ophthalmic artery, cavernous sinus meningiomas, giant pituitary adenomas, and aneurysms at the apex of the basilar artery and the posterior communicating artery (Beger et al.; Chaddad-Neto et al.; Xu et al.; Skandalakis et al.).

As for the middle clinoidectomy, it can be requested in craniopharyngiomas, meningiomas, and pituitary adenomas (Skandalakiset al.). The posterior clinoidectomy, however, is required to remove barriers that may obstruct access, via endoscopy, to the prepontine and interpeduncular cistern lesions (Rejane-Heim et al., 2021). Nevertheless, anterior clinoidectomy is associated with several surgical risks, such as visual disturbances, oculomotor nerve palsy, opening of the cavernous sinus and hemorrhages from ICA injuries, rupture of the ophthalmic artery, fistulous communications from the sinuses to the cerebrospinal fluid, and the potentially fatal course of meningitis (Prathiba et al.; Chaddad-Neto et al.; Jha et al.). Among these complications, optic nerve lesion is the most common. In this sense, the presence of these bone rings implies a medial fixation of the ACP, complicating anterior clinoidectomy and increasing the risk of injury to adjacent structures (Prathiba et al.; JaiSankar et al.; Skandalakis et al.; Touska et al.). As for ICA pathologies, the presence of CF impairs mobilization of the cavernous segment and can compress it, possessing considerable clinical significance (Efthymiou et al., 2018; Prathiba et al.). In addition, there is a necessity for other maneuvers to access aneurysms in the ICA when the CF and IF are present, which increases the risk of a vascular rupture. Other repercussions of these variations include difficulties in removing central tumors, identification of the MCP - commonly used as an anatomical reference during nasal endoscopies to access the hypophysis gland - and diagnostic difficulties by professionals unaccustomed to ligament ossifications when conducting angiographies (Touska et al.).

Therefore, knowledge and anatomical study of the $\mathrm{CF}$ and IF are essential for surgical planning. The conventional and two-dimensional CT scans may not detect the presence of $\mathrm{CF}$, so coronal and three-dimensional thinsection reconstructions are necessary, especially on axial sections at the level of the upper parasellar region. Thus, the surgeon should be attentive even if the canal is not detected in these exams and, if it is identified, should prioritize the anterior intradural compared to extradural clinoidectomy, because it offers better visualization and lesser risk of injury to the ICA (Skandalakis et al.; Jean, 2019). Besides surgical obstacles, the presence of the canal can compress or tension the ICA, with possible alteration in cerebral blood circulation (Singh). In addition, the IF may be a potential cause of trigeminal neuralgia (Bayrak et al.).

The present study demonstrated an incidence of ligamentary ossifications between the clinoid processes of $28.95 \%(11: 38)$ in the skulls evaluated, disregarding the age and the sex, and of the 11 skulls, the CF formation occurred in $54.54 \%(6: 11)$ and the IF in $45.45 \%(5: 11)$. Touska et al. evaluated 240 skulls using Computed Tomography (CT) and identified the CF in $17.5 \%$ of them (42:240), of which $25(59.5 \%)$ were bilateral, and of these $60 \%$ (15:25) were complete, $24 \%$ (6:25) were mixed - complete on one side and incomplete on the other, and $16 \%$ (4:25) were incomplete, and of the unilateral ones $(17: 42)$, $52.9 \%(9: 17)$ were complete and $47.1 \%(8: 17)$ were incomplete.

In addition, $53(22.1 \%)$ of the 240 skulls presented the IF, with 24 (45.3\%) being bilateral, of which $29.2 \%$ (7:24) were complete, $12.5 \%(3: 24)$ mixed and $58.3 \%$ (14:24) incomplete, and $29(54.7 \%)$ being unilateral, with $20.7 \%(6: 29)$ of them complete and $79.3 \%(23: 29)$ incomplete. Both formations, CF and IF, have been found in skulls of all ages. The author found an average thickness and length of $1.8 \mathrm{~mm}(\mathrm{SD}=0.8 \mathrm{~mm})$ and $25.3 \mathrm{~mm}(\mathrm{SD}=$ $4.4 \mathrm{~mm})$ in CFs and $1.8 \mathrm{~mm}(\mathrm{SD}=0.5 \mathrm{~mm})$ and $75.2 \mathrm{~mm}$ $(\mathrm{SD}=22 \mathrm{~mm})$ in IFs, respectively. The thickness measurements were not recorded in this study in the $\mathrm{CF}$ or the IF, but the average length of the osseous bridge from the $\mathrm{ACP}$ to the PCP (bone bar of the IF) was $7.7 \mathrm{~mm}(\mathrm{SD}=0.51$ $\mathrm{mm})$.

Jaisankar et al., identified the CF in 29 (58\%) of the 50 skulls evaluated, although none of them presented complete conformation, with 16 of them (32\%/55.2\% - 16:50/ 16:29) unilateral and 13 (26\%/44.8 \% - 13:50/13:29) bilateral. On the other hand, the author did not locate the IF in the skulls in question. As for the left CFs, the average vertical length and transverse length were $5.237 \mathrm{~mm}(\mathrm{SD}=1.121$ $\mathrm{mm})$ and $6.393 \mathrm{~mm}(\mathrm{SD}=2.159 \mathrm{~mm})$, respectively, in the male skulls and $5.226 \mathrm{~mm}(\mathrm{SD}=0.630 \mathrm{~mm})$ and $5.862 \mathrm{~mm}$ $(\mathrm{SD}=1.599 \mathrm{~mm})$ in the female skulls. On the right side, the $\mathrm{CF}$ presented average vertical length and transverse length of $4.435 \mathrm{~mm}(\mathrm{SD}=1.001 \mathrm{~mm})$ and $4.669 \mathrm{~mm}(\mathrm{SD}=1.660$ $\mathrm{mm})$ in male skulls, respectively, and $4.719 \mathrm{~mm}(\mathrm{SD}=0.959$ $\mathrm{mm})$ and $4.193 \mathrm{~mm}(\mathrm{SD}=1.706 \mathrm{~mm})$ in female skulls. 
DE OLIVEIRA, K. M.; DE ALMEIDA, V. L.; BENEVENUTO, G. C.; DE FARIA, G. M.; SILVA, A. C. C.; COSTA, T. C. F.; DE OLIVEIRA, D. G.; BUENO, L. B.; RODRIGUES, P. L.; PEIXOTO, M. T. C.; GOMES, T. C.; OLIVEIRA, M. F. S.; GONÇALVES, G. R. \& GRECCO, L. H. Morphometric analyses of the caroticoclinoid and interclinoid foramina: A study in Brazilian dry skulls. Int. J. Morphol., 39(5):1345-1352, 2021.

In the present study, only complete foramina were considered, there was no distinction between female and male skulls and ages were not considered either. Thus, the incidence of $\mathrm{CF}$ on the right side was $62.5 \%$ (5 of 8 formations in total - uni and bilateral). The right unilateral variation was $50 \%$ (3 of 6 skulls). We did not consider CF formations associated with IF formations (3 findings). The left unilateral variation occurred isolated in 1:6 skulls (16.66 $\%)$ and, when associated with bilateral findings, the incidence was $50 \%$ (3 of 6 skulls). The T-diameter averaged $4.91 \mathrm{~mm}$, with right positioned foramina averaging $4.84 \mathrm{~mm}$ and left positioned foramina averaging $5.03 \mathrm{~mm}$ with $\mathrm{SD}=0.42 \mathrm{~mm}$. As for the AP (anteroposterior) diameter, we obtained an average of $5.82 \mathrm{~mm}$, with the foramina positioned on the right having an average of $5.68 \mathrm{~mm}$, and the foramina positioned on the left having an average of $6.07 \mathrm{~mm}$, with $\mathrm{SD}=0.53 \mathrm{~mm}$.

The area of the CFs averaged $22.5 \mathrm{~mm}^{2}$. with the right foramina averaging $21.6 \mathrm{~mm}^{2}$ and the left foramina $24.1 \mathrm{~mm}^{2}$ and $\mathrm{SD}=3.43 \mathrm{~mm} 2$. Bayrak et al., studied 573 patients, 246 (42.9\%) women and $327(57.1 \%)$ men, via cone beam computed tomography to detect the presence of intracranial ligamentous ossifications, and reported $28(4.88$ $\%)$ IF findings, $16(2.79 \% / 57.14 \%-16: 573 / 16: 28)$ of them being unilateral and 12 bilateral $(2.09 \% / 42.86 \%-12: 573 /$ $12: 28)$. In addition, there were $22(3.83 \%) \mathrm{CFs}$, of which 6 $(1.04 \% / 27.3 \%-6: 573 / 6: 22)$ were unilateral and 16 (2.79 $\% / 72.7 \%$ - 16:573/16:22) were bilateral.

In all, the authors identified $50(8.72 \%)$ foramina in the skulls evaluated and reported that there was no statistical difference according to age, sex or side where the canal was observed. On the other hand, Skandalakis et al., in a metaanalysis and systematic review study of 26 works about CF, reported an overall prevalence of $32.6 \%$ (95\% confidence interval [CI], $26.6 \%$ and $38.8 \%$ ), being the prevalence of bilateral $41.1 \%$ (95\% CI, $31.9 \%$ and $50.5 \%$ ), of these $46.8 \%(95 \%$ CI, $39.4 \%$ and $54.3 \%$ ) were complete or contact type, and unilateral $23.6 \%$ (95\% CI, $19.7 \%$ and $27.6 \%$ ), of these $46.0 \%$ (95\% CI, $38.8 \%$ and $53.2 \%$ ) were complete or contact type. Differently from the study by Bayrak et al., the authors noted a statistically significant right dominance in unilateral CFs (odds ratio for right vs. left, $1.11 ; \mathrm{P} \approx 0.050$ ).

In the work of Bansode et al. (2017), it was reported that, of the 35 skulls studied, only 7 (20\%) presented the CF. In these skulls, $2(5.7 \% / 28.6 \%-2: 35 / 2: 7)$ had the complete bilateral CF, $2(5.7 \% / 28.6 \%-2: 35 / 2: 7)$ complete right unilateral, $2(5.7 \% / 28.6 \%-2: 35 / 2: 7)$ incomplete, in right unilateral and $1(2.8 \% / 14.3 \%-1: 35 / 1: 7)$ incomplete left unilateral.
The incidence of ossification of the caroticoclinoid ligament was consequently $12.8 \%$ (9:70), with $8.57 \% / 66.7$ $\%(6: 70 / 6: 9)$ complete and $4.28 \% / 33.3 \%(3: 70 / 3: 9)$ incomplete. Similarly to Skandalakis et al., who identified right dominance with respect to the unilateral presence of the CF. According to Efthymiou et al., of the 76 adult human skulls analyzed, $56(74 \%)$ of them had the CF. The bilateral occurrence was $51.3 \% / 69.6 \%$ (39:76/39:56) and only 17 (22.3\%/30.4\% - 17:76/17:56) skulls had the CF unilaterally, with limited right dominance of $53 \%$ (9:17). Independent of sex or age, the CF was incomplete in $69.6 \%$ (39) of the findings, complete in $19.6 \%$ (11), and of contact in $10.7 \%$ (6).

The average transverse diameter of CFs was 5.500 $\mathrm{mm}(\mathrm{SD}=0.700 \mathrm{~mm})$ on the left side and $5.400 \mathrm{~mm}(\mathrm{SD}=$ $0.800 \mathrm{~mm}$ ) on the right. Jha et al., conducted a study on $\mathrm{CF}$ in 108 adult human skulls. The authors observed that CF was present in $24(22.22 \%)$. Of these, 15 (62.5\%) were unilateral - with left dominance, what differs from the other studies, and only $9(37.5 \%)$ were bilateral. The incomplete CF type was more prevalent, present in $14 \% / 62.5 \%$ (15:108/ 15:24) of the skulls, against $8.3 \% / 37.5 \%$ (9:108/9:24) complete. Prathiba et al., studied, in 100 dry human skulls, the presence of the CF and CL. Of these, only $12(12 \%)$ presented ossified CL and CF, and $7 \% / 58.3 \%(7: 100 / 7: 12)$ were on the left side and $5 \% / 41.7 \%(5: 100 / 5: 12)$ on the right side. This study also evaluated the anteroposterior, transverse CF diameters. As a result, the average anteroposterior and transverse diameters were $5.35 \mathrm{~mm}$ (SD $=0.3 \mathrm{~mm})$ and $5.09 \mathrm{~mm}(\mathrm{SD}=0.16 \mathrm{~mm})$, respectively, on the right side, and $4.49 \mathrm{~mm}(\mathrm{SD}=0.28 \mathrm{~mm})$ and $5.41 \mathrm{~mm}$ $(\mathrm{SD}=0.17 \mathrm{~mm})$, on the left side. The maximum anteroposterior diameter on the right side was $5.83 \mathrm{~mm}$, being greater than on the left side, with $4.54 \mathrm{~mm}$. The maximum transverse diameter on the right side was 5.30 $\mathrm{mm}$, showing to be smaller than the left side with $5.57 \mathrm{~mm}$. Table V summarizes recent works, including the present study, as regards the incidences of caroticoclinoid (CF) and interclinoid (IF) foramina.

\section{CONCLUSION}

The incidence of ligament ossifications - CF and IF, in the present study, differs from the findings of other publications, which is expected in view of the different human groups investigated. However, studies demonstrate a considerable prevalence of CF and IF and the necessity of detailed knowledge of their possible morphologies and morphometry in order to prevent surgical complications. Thus, studies are still needed to completely understand these variations and their clinical and epidemiological relevance. 
DE OLIVEIRA, K. M.; DE ALMEIDA, V. L.; BENEVENUTO, G. C.; DE FARIA, G. M.; SILVA, A. C. C.; COSTA, T. C. F.; DE OLIVEIRA, D. G.; BUENO, L. B.; RODRIGUES, P. L.; PEIXOTO, M. T. C.; GOMES, T. C.; OLIVEIRA, M. F. S.; GONÇALVES, G. R. \& GRECCO, L. H. Morphometric analyses of the caroticoclinoid and interclinoid foramina: A study in Brazilian dry skulls. Int. J. Morphol., 39(5):1345-1352, 2021.

Table V. Recent studies on anatomical findings of the CF (caroticoclinoid) and IF (interclinoid) foramen. * The study by Touska et al. (2019) was conducted in $62.5 \%$ white British/European, $18.3 \%$ black British/African and Caribbean, $11.3 \%$ Indian and $7.9 \%$ other ethnic groups. ** Meta-analysis study.

\begin{tabular}{|c|c|c|c|c|}
\hline Author & Population & Year & Specimens & Findings \\
\hline Touska et al. & British * & 2019 & 240 & 42 skulls $(17.5 \%)$ presented $\mathrm{CF}$ and $53(22.1 \%)$ the IF. \\
\hline Jaisankar et al. & Indian & 2019 & 50 & 29 skulls (58\%) presented $\mathrm{CF}$ and none the FI. \\
\hline Bayraketal. & Turkish & 2019 & 573 & 22 skulls $(3.83 \%)$ presented CF and $28(4.88 \%)$ the IF. \\
\hline Skandalakis et al. & $\begin{array}{l}\text { Non-specified } \\
* *\end{array}$ & 2019 & $\begin{array}{l}\text { Meta-analysis } \\
\text { of } 26 \text { studies }\end{array}$ & $\begin{array}{l}\text { CF prevalence in } 32.6 \% \text { ( } 95 \% \text { confidence interval }[\mathrm{CI}] \text {, } \\
26.6 \% \text { and } 38.8 \%) \text {. }\end{array}$ \\
\hline Bansode et al. & Indian & 2017 & 35 & In 35 skulls only 7 ( $20 \%$ ) presented the CF. \\
\hline Jha et al. & Indian & 2017 & 108 & $\begin{array}{l}24 \text { skulls presented CF with a p revalence of } 22.22 \% \\
\text { (108 skulls in total). }\end{array}$ \\
\hline Efthymiou et al. & Greek & 2018 & 76 & In 76 skulls studied, CF was present in $56(74 \%)$. \\
\hline Prathiba et al. & Indian & 2020 & 100 & $\begin{array}{l}\text { Analyzed } 100 \text { skulls, } 12 \text { showed CF with a prevalence of } \\
12 \% \text {. }\end{array}$ \\
\hline Present study & Brazilian & 2021 & 38 & $\begin{array}{l}\text { Of the total of } 11 \text { skulls }(28.95 \%) 6 \text { showed the CF and } \\
\text { the other } 5 \text { the IF. }\end{array}$ \\
\hline
\end{tabular}

DE OLIVEIRA, K. M.; DE ALMEIDA, V. L.; BENEVENUTO, G. C.; DE FARIA, G. M.; SILVA, A. C. C.; COSTA, T. C. F.; DE OLIVEIRA, D. G.; BUENO, L. B.; RODRIGUES, P. L.; PEIXOTO, M. T. C.; GOMES, T. C.; OLIVEIRA, M. F. S.; GONÇALVES, G. R. \& GRECCO, L. H. Análisis morfométricos del foramen caroticoclinoideo e interclinoideo: Un estudio en cráneos secos brasileños. Int. J. Morphol., 39(5):1345-1352, 2021.

RESUMEN: El foramen caroticoclinoideo (FC) y el foramen interclinoideo (IC) son formaciones variables de la fosa craneal media, que resultan de osificaciones idiopáticas y posiblemente atávicas de los ligamentos caroticoclinoideo e interclinoideo, respectivamente. Estos forámenes están íntimamente asociados topográficamente en diversos grados, dependiendo de sus conformaciones, con los elementos neurovasculares de la región paraclinoidea y tienen importancia clínica y quirúrgica. Así, este estudio, realizado a partir de 38 cráneos secos pertenecientes a la colección compartida de la Universidad Federal de Juiz de Fora, campus Governador Valadares, reveló 11 cráneos $(28,95 \%)$ con una de las dos formaciones completas: el FC o el IC, y en 6 cráneos el FC se presentó uni o bilateralmente. Como resultado, el $50 \%$ de estos cráneos presentaba el FC exclusivamente a la derecha (o el 62,5\% del total de forámenes variantes), con un diámetro transversal medio de $4,91 \mathrm{~mm}$ y un diámetro anteroposterior medio de $5,8 \mathrm{~mm}$ y un área promedio de 22,5 $\mathrm{mm}^{2}$. En cuanto a la FI, los hallazgos se presentaban en 5 cráneos con distribuciones variables entre los procesos clinoides y lateralidades. La longitud media de los puentes óseos en el FI fue de 7,7 mm. En conclusión, el conocimiento anatómico detallado de los forámenes caroticoclinoideo e interclinoideo resulta fundamental para la práctica de procedimientos neuroquirúrgicos, ya que presentan relaciones íntimas en un lugar de alta complejidad estructural.

PALABRAS CLAVE: Caroticoclinoide y cirugía; Foramen caroticoclinoide y ligamento caroticoclinoide.

\section{REFERENCES}

Bansode, S. A.; Devadas, P. \& Vinila, B. H. S. Study on the incidence of the carotico-clinoide foramen in the south indian dry adults skulls: a cross-sectional study. Int. J. Anat. Res., 5:4051-5, 2017.

Bayrak, S.; Bulut, D. G.; Çakmak, E. S, K. \& Orhan, K. Cone beam computed tomographic evaluation of intracranial physiologic calcifications. J. Craniofac. Surg., 30(2):510-3, 2019.

Beger, O.; Hamzaoglu, V.; Özalp, H.; Taghipour, P.; Çakir, S.; Akbulut,

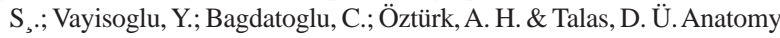
of the anterior clinoid process in human fetuses. J. Craniofac. Surg., 31(5):1469-73, 2020.

Chaddad-Neto, F.; da Costa, M. D. S.; Santos, B.; Caramanti, R. L.; Costa, B. L.; Doria-Netto, H. L. \& Figueiredo, E. G. Reproducibility of a new classification of the anterior clinoid process of the sphenoid bone. Surg. Neurol. Int., 11:281, 2020.

de Oliveira, K. M.; de-Almeida, V. L.; López, C. A. C.; Brandão, G. T.; Trancoso, M. G. B.; Oliveira, M. F. S.; Morais, I. C. L.; Soares, D. C. B. \& Costa, L. C. M. The pterygospinous foramen (Civinini) and the pterygoalar (crotaphitico-buccinatorius). Laboratory Findings. Int. J. Morphol., 39(1):198-204, 2021.

Efthymiou, E.; Thanopoulou, V.; Kozompoli, D.; Kanellopoulou, V.; Fratzoglou, M.; Mytilinaios, D.; Piagkou, M. \& Johnson, E. O. Incidence and morphometry of caroticoclinoid foramina in Greek dry human skulls. Acta Neurochir(Wien), 160(10):1979-87, 2018.

Henle, G. J. Handbuch der systematischen Anatomie des Menschen. Braunschweig, Friedrich Vieweg und Sohn, 1855. pp.97-112.

Isolan, G. R.; Braga, F. L. S.; Campero, A.; Landeiro, J. A.; de Araújo, R. M. L.; Adjer, P.; Sakaya, G. R.; Rabelo, N. N.; da Silva Brito, J.; Teixeira, M. J.; et al. Microsurgical and endoscopic anatomy of the cavernous sinus. Arq. Bras. Neurocir., 39(2):83-94, 2020.

JaiSankar, A. I.; Lakshmanan, G. \& Thenmozhi, M. S. Occurrence of caroticoclinoid foramen and inter clinoid bar in dry human skulls and their clinical significance. Drug Invent. Today, 11(5):1021-6, 2019.

Jean, W. C. How I do it: extradural clinoidectomy. Acta Neurochir. (Wien), 161(12):2583-6, 2019.

Jha, S.; Singh, S.; Bansal, R.; Chauhan, P.; Shah, M. P. \& Shah, A. Nonmetric analysis of caroticoclinoid foramen in foothills of Himalayas: Its clinicoanatomic perspective. Morphologie, 101(332):47-51, 2017.

Prathiba, K.; Kumari, M. K. L.; Sreekanth, C. \& Srivani, D. A Study on Ossified Carotico-Clinoid Ligament in Human Skulls in Rayalaseema Zone. IOSR J. Dent. Med. Sci., 19(1):30-3, 2020. 
DE OLIVEIRA, K. M.; DE ALMEIDA, V. L.; BENEVENUTO, G. C.; DE FARIA, G. M.; SILVA, A. C. C.; COSTA, T. C. F.; DE OLIVEIRA, D. G.; BUENO, L. B.; RODRIGUES, P. L.; PEIXOTO, M. T. C.; GOMES, T. C.; OLIVEIRA, M. F. S.; GONÇALVES, G. R. \& GRECCO, L. H. Morphometric analyses of the caroticoclinoid and interclinoid foramina: A study in Brazilian dry skulls. Int. J. Morphol., 39(5):1345-1352, 2021.

Rejane-Heim, T. C.; Silveira-Bertazzo, G.; Carrau, R. L. \& Prevedello, D. M. Surgical anatomy and nuances of the expanded endonasal transdorsum sellae and posterior clinoidectomy approach to the interpeduncular and prepontine cisterns: a stepwise cadaveric dissection of various pituitary gland transpositions. Acta Neurochir., 163(2):40713, 2021.

Sharma, A.; Rieth, G. E.; Tanenbaum, J. E.; Williams, J. S.; Ota, N.; Chakravarthi, S.; Manjila, S.; Kassam, A. \& Yapicilar, B. A morphometric survey of the parasellar region in more than 2700 skulls: emphasis on the middle clinoid process variants and implications in endoscopic and microsurgical approaches. J. Neurosurg., 129(1):6070, 2019.

Singh, R. Carotico-clinoid foramen and associated clinical significance: comprehensive review. Cureus, 13(1):e12828, 2021.

Skandalakis, G. P.; Koutsarnakis, C.; Pantazis, N.; Kalyvas, A.; Komaitis, S.; Lani, E.; Drosos, E.; Kalamatianos, T.; Hadjipanayis, C. G.; Natsis, $\mathrm{K}$.; et al. The carotico-clinoid bar: A systematic review and metaanalysis of its prevalence and potential implications in cerebrovascular and skull base surgery. World Neurosurg., 124:267-76, 2019.

Touska, P.; Hasso, S.; Oztek, A.; Chinaka, F. \& Connor, S. E. J. Skull base ligamentous mineralisation: evaluation using computed tomography and a review of the clinical relevance. Insights Imaging, 10:55, 2019.

Xu, T.; Yan, Y.; Evins, A. I.; Gong, Z.; Jiang, L.; Sun, H.; Cai, L.; Wang, H.; Li, W.; Lu, Y.; et al. Anterior clinoidal meningiomas: meningeal anatomical considerations and surgical implications. Front. Oncol., 10:634, 2020.

Zhao, X.; Labib, M. A.; Avci, E.; Preul, M. C.; Baskaya, M. K.; Little, A. S. \& Nakaji, P. Navigating a carotico-clinoid foramen and an interclinoidal bridge in the endonasal endoscopic approach: an anatomical and technical note. J. Neurol. Surg. B Skull Base, 2020. DOI: https:// www.doi.org/10.1055/s-0040-1715470
Corresponding author:

Kennedy Martinez de Oliveira.

Federal University of Juiz de Fora

Minas Gerais

BRAZIL

Department of Basic Life Sciences

Federal University of Juiz de Fora

São Paulo Street 745

Governador Valadares

CEP 35010-180.

Minas Gerais

BRAZIL

E-mail: kennedy.martinez@gmail.com

Received: 23-04-2021

Accepted: 11-07-2021 